Swart, I. (2017). Social capital, religious social capital and the missing element of religious

ritual.

Religion and Theology, 24: $221-249$

http://dx.doi.org/10.1163/15743012-02403008

\title{
Social capital, religious social capital and the missing element of religious ritual
}

\author{
Ignatius Swart
}

\begin{abstract}
This article was written to contribute towards developing a suitable conceptual framework for meeting the overarching research aim of developing a more profound empirically informed interpretation of the manner and extent to which religious ritual could be valued as a source of social capital formation in the South African context. With this in mind, the article first explores the concept of social capital in the light of the threefold distinction between bonding, bridging and linking forms of social capital. Secondly, from the vantage point of such exploration the connection with religion is made more pointedly. By tapping into the more recently invented notion of religious social capital, the article shows how this concept is today used meaningfully to advance a twofold perspective: on religion as a special repository of social capital, but also on the limitations of religion and its institutions in meeting the social capital needs of communities and the wider society. Finally, from the viewpoint of eliciting important conceptual value from the notion of religious social capital, the case of religious ritual as a very necessary yet untapped element in the contemporary research focus on religion and social capital formation is presented. In particular, an argument about religious ritual as the consistently missing element in this research focus is put forward and given greater substance through the identification of two pointers from the literature that can be deemed useful in starting to address this lacuna.
\end{abstract}

\section{$1 \quad$ Introduction}

This article constitutes the latest outcome of my scholarly undertaking of the last decade and a half to develop a focus on the concept of social capital ${ }^{1}$ as part of a larger South African research interest in the field of religion and development. ${ }^{2}$ From this vantage point the article more

\footnotetext{
1 The development of this focus first gained momentum when I was granted the opportunity to lead a research project funded by the National Research Foundation (nrf) with the working title, "Developing a Praxis for Mobilising Faith-Based Organisations for Social Capital and Development in the Western Cape" (short title: "fbos, Social Capital and Development"). The project was formally funded in the period 2004 to 2006 and, besides a number of articles and chapters, led to a major book publication in which several chapters by contributing authors, including my own, give evidence of the focus on social capital. See Ignatius Swart, Hermann Rocher, Sulina Green and Johannes Erasmus, eds., Religion and Social Development in Post-Apartheid South Africa: Perspectives for Critical Engagement (Stellenbosch: sun Press, 2010); Ignatius Swart, "Networks and Partnerships for Social Justice? The Pragmatic Turn in the Religious Social Development Debate in South Africa," $r \& t$ 12, no. 1 (2005): 20-47; Ignatius Swart, "Churches as a Stock of Social Capital for Promoting Social Development in Western Cape Communities," Journal of Religion in Africa 36, no. 3-4 (2006): 346-378; Ignatius Swart, "Religion and Social Capital Research in South Africa: Mapping an Agenda in Progress", in Religion and Social Problems, ed. Titus Hjelm, Routledge Advances in Sociology (New York, ny: Routledge, 2011), 98-121.

${ }^{2}$ The titles of the literature listed in footnote 1 give clear evidence of how my fellow researchers and I have found special value and relevance in the concept of social development to pursue such a research interest in the field of religion and development. In particular,
} 
pertinently reflects aspects of the conceptual progress made since the publication of an initial article 3 on the project work that would be undertaken by an international team of researchers on the role of religious ritual in the kinds of social capital formation relevant to the related objectives of alleviating poverty and promoting social development in poor South African communities. 4

This article was specifically written with a view to contribute towards designing a suitable conceptual framework for meeting the aforementioned project's overarching research aim of developing a more profound empirically informed interpretation of the manner and extent to which religious ritual could be valued as a source of social capital formation. 5 With such a conceptual framework in mind, I begin the discussion by firstly embarking on some deeper exploration of the concept of social capital along the lines of what has become a familiar and popular typology in academic debates: the distinction between "bonding", "bridging" and "linking" social capital. Secondly, from the vantage point of this exploration I then move on to make more pointedly the connection with religion. By tapping into the more recently invented notion of "religious social capital", the discussion shows how this concept (religious social capital) is today meaningfully used in the literature to advance a twofold perspective: on religion as a special repository of social capital, but also on the limitations of religion and its institutions in meeting the social capital needs of communities and larger societies. Finally, from the viewpoint of finding important conceptual value in the notion of religious social capital, I bring the discussion to a close by more pertinently presenting the case of religious ritual as a very necessary yet untapped element in the contemporary international research focus on religion and social capital formation. In particular, I put forward an argument about religious ritual as the consistently "missing element" in such research focus and in the process conclude with two pointers from the literature that can be deemed useful in starting to address the missing element.

\footnotetext{
the concept of social development denoted post-apartheid South Africa's adoption of a development approach to social welfare, which we found particularly suitable as an ideal concept to also think about the religious sector's participation in the post-apartheid development challenge. See Ignatius Swart, Hermann Rocher, Sulina Green and Johannes Erasmus, "Introduction," in Religion and Social Development in Post-Apartheid South Africa, 1-12; Ignatius Swart, "Transforming Social Welfare? The Religious Discourse on Social Development in Post-Apartheid South Africa," in Welfare, Religion and Gender in Post-Apartheid South Africa: Constructing a South-North Dialogue, eds. Ignatius Swart, Amanda Gouws, Per Pettersson, Johannes Erasmus and Frouwien Bosman (Stellenbosch: sun Press, 2012), 65-93.

${ }^{3}$ Published in 2010 in this journal $(r \& t)$, this article also belongs to the group of publications identified in footnote 1 , but is listed separately here because of the specific phase in my research focus on social capital that I am giving an account of in the present article. Cas Wepener, Ignatius Swart, Gerrie ter Haar and Marcel Barnard, "The Role of Religious Ritual in Social Capital Formation for Poverty Alleviation and Social Development. Theoretical and Methodological Points of Departure of a South African Exploration," $r \& t$ 22, no. 3\&4 (2010):61-82.

${ }^{4}$ The project was formally funded by the nrf in the period 2008-2011 under the working title, "Exploring the Role of Religious Ritual in Social Capital Formation for Poverty Alleviation and Social Development in Poor South African Communities." As such the conceptual link between this project and the project on "fbos, Social Capital and Development" (see footnote 1) has been acknowledged from the outset, while it would at the same time be recognised that the innovative element of the new round of project work would be its focus on the question of religious ritual specifically as a generator of social capital. See Swart, "Religion and Social Capital Research in South Africa," 117-118; Wepener et al., "The Role of Religious Ritual in Social Capital Formation," 62-63.

5 As the title of the manuscript mentioned in the starred $\left(^{*}\right)$ footnote at the beginning of this article suggests, the focus would fall on particular congregations from the African Independent Churches to develop an empirical perspective. See Wepener et al., "The Role of Religious Ritual in Social Capital Formation;" Wepener et al., Bread \& Wine \& Kentucky Fried Chicken.
} 
In his important work on the evolution of social capital as an aspect of the social science and policy debate, John Field meaningfully asserts that "social capital began as a comparatively simple concept". ${ }^{6}$ The central thesis of social capital theory, Field contends, could initially be summed up in two words: "relationships matter":7

By making connections with one another, and keeping them going over time, people are able to work together to achieve things that they either could not achieve by themselves, or could only achieve with great difficulty. People connect through a series of networks and they tend to share common values with other members of these networks; to the extent that these networks constitute a resource, they can be seen as forming a kind of capital. ${ }^{8}$

However, Field importantly continues by pointing out how the notion of social capital has from such an initial straightforward understanding "evolved rapidly into a rather more complex account of people's relationships and their value". ${ }^{9}$ In this regard, he goes on to discuss at length how the growth of a more complex understanding would evolve in scholarly debates, especially since the 1980s, in the work of three social science scholars: Pierre Bourdieu, James Coleman and Robert Putnam..$^{10}$ In terms of this identification, he goes so far as to describe these scholars as "the three outstanding theorists of social capital", ${ }_{11}$ who each in their own way laid the foundation for a more sophisticated understanding of social capital. ${ }^{12}$

This article does not allow me the space to relate to the detail of Field's discussion of the virtues of Bourdieu's, Coleman's and Putnam's contributions to developing the conceptual apparatus of social capital. Rather, in view of the direction in which I want to steer the discussion, I want to point to another qualification in Field's discussion. Whilst expressing his appreciation for the foundational contribution of the three scholars, it becomes striking to note how he ultimately concludes with a statement about the conceptual limitations of the theoretical work on social capital of these three scholars. These limitations included their understatement of the importance of powerinequalities, the gender-blindness of their work, the way they downplay the negative consequences of social capital, the somewhat ahistorical nature of their foundational approaches, and the inability of their foundational definitions to distinguish between different types of social capital. ${ }^{13}$

\footnotetext{
${ }^{6}$ John Field, Social Capital (London: Routledge, 2003), 136.

${ }^{7}$ Field, Social Capital, 1.

${ }^{8}$ Field, Social Capital, 1.

${ }^{9}$ Field, Social Capital, 136.

${ }^{10}$ See Field, Social Capital, 11-43. For a similar recognition of the contribution of Bourdieu, Coleman and Putnam, see Mark K. Smith, "Social Capital," The Encyclopedia of Informal Education, http://infed.org/mobi/social-capital/, 2000-2009, retrieved 20 March 2014.

${ }^{11}$ See Field, Social Capital, 1-2.

12 In a summary of his appreciation of the three scholars' contributions Field observes that they have each contributed in different ways to the idea of "networks and relationships as a resource": Bourdieu in the way in which he considered social capital as an asset used by elite groups; Coleman in the way in which he contended that social capital could also serve as a resource for relatively disadvantaged individuals and families; and Putnam in the way in which he extended the idea of social capital as a resource that functions at the societal level. See Field, Social Capital, 40.

${ }^{13}$ See Field, Social Capital, 40-42.
} 
As part of my own attempt at making sense of the ongoing scholarly debate on social capital, I want to engage with Field's critical qualification of the conceptual value of Bourdieu's, Coleman's and Putnam's theoretical work on social capital to clarify my conceptual position in this article. In particular,I especially want to take into consideration Field's concluding observation that despite the contribution by Bourdieu, Coleman and Putnam towards developing a more complex account of social capital, their "initial conceptions remain somewhat sketchy and loose", ${ }^{14}$ and that it is in fact in the work of subsequent scholars that the initial conceptions of social capital "have been stretched to fit a wide variety of hypotheses and models". 15

From the standpoint of Field's identification of a broader and more differentiated conceptual framework that has evolved in social capital scholarship over the years, beyond the foundational work of Bourdieu, Coleman and Putnam, in this article I want to draw upon one particular contribution to a broader and more differentiated conceptualisation. More specifically, my conceptual choice falls on what has undoubtedly become one of the most popular and frequently applied conceptual frameworks in the scholarly world of contemporary social capital research: the distinction between different types of social capital referred to as "bonding", "bridging" and "linking" social capital. ${ }^{16}$

As Field acknowledges, ${ }^{17}$ it is the work of Michael Woolcock that best explains the original conceptualisation of the threefold typology of bonding, bridging and linking social capital, as I will indicate briefly in the rest of this section. ${ }^{18} \mathrm{~A}$ sociologist by training, Woolcock has risen to prominence through his work as a Social Development Specialist with the Development Research Group of theWorld Bank. ${ }^{19}$ In this capacity, as a fervent advocate of theidea (or thesis) that "relationships within and between social groups at different levels of society [read: social capital] shape the prospects for sustainable, equitable growth and just, participatory governance", ${ }^{20}$ he has been instrumental in promoting the Bank's embracement of the concept of social capital to reinvigorate its theoretical and strategic thinking about social development since the late $1990 .^{21}$

Against this backdrop, an important feature of Woolcock's work on social capital is that he has not shied away from discussing and acknowledging the theoretical and empirical weaknesses of

\footnotetext{
${ }^{14}$ Field, Social Capital, 136.

${ }^{15}$ Field, Social Capital, 136.

${ }^{16}$ A search on Google Scholar clearly reveals a staggering list of literature published over the last decade and a half.

${ }^{17}$ Field, Social Capital, 42.

${ }^{18}$ Limitations of space make it more appropriate for me to acquaint myself with the original ideas from Woolcock's work rather than exploring the vast corpus of literature referred to in footnote 16.

19 See The World Bank, "Michael Woolcock: Lead Social Development Specialist, Development Research Group," http://www.worldbank.org/en/about/people/m/michaelwoolcock, n.d., retrieved 3 March 2015.

${ }^{20}$ Michael Woolcock, "Social Capital and Economic Development: Towards a Theoretical Synthesis and Policy Framework", Theory and Society 27, no. 2 (1998): 188; see also Michael Woolcock, "The Place of Social Capital in Understanding Social and Economic Outcomes", Development Research Group, The World Bank, and Kennedy School of Government, Harvard University, 25, www.oecd.org/innovation/research/1824913.pdf, 2001, retrieved 1 February 2015; Michael Woolcock and Deepa Narayan, "Social Capital: Implications for Development Theory, Research, and Policy," The World Bank Research Observer 15, no. 2 (2000): 227-228, 243.

${ }^{21}$ For a critical discussion of the Bank's adoption of social capital as part of its conceptual and policy apparatus, see Anthony Bebbington, Scott Guggenheim, Elizabeth Olson and Michael Woolcock, "Exploring Social Capital Debates at the World Bank," The Journal of Development Studies 40, no. 5 (2004): 33-64.
} 
the concept raised in theoretical debates. ${ }^{22}$ Amongst these are the accusations that as a single term social capital is "inadequate to explain the range of empirical situations demanded from it, that it confuses sources with consequences, justifies contradictory social policies, and understates corresponding negative aspects". ${ }^{23}$ Most importantly, however, for Woolcock these criticisms are not sufficient to dismiss the concept of social capital altogether. Instead, it is necessary to adopt and apply a more dynamic understanding of social capital: one in which a distinction could be made between different types, levels or dimensions of social capital; different performance outcomes associated with different combinations of the various dimensions; and different sets of conditions that support or weaken the different combinations. ${ }^{24}$

The distinction between bonding, bridging and linking social capital, then, has become an important element of Woolcock's own attempt to work towards a more dynamic and differentiated understanding of social capital. 25 Taking his point of departure in the relatively simple and straightforward definition of social capital as referring "to the norms and networks that enable people to act collectively", ${ }^{26}$ he has argued that this simple definition serves a number of purposes: first, "it focuses on the sources, rather than the consequences of social capital ... while recognizing that important features of social capital, such as trust and reciprocity, are developed in an iterative process"; 27 and second, it allows for "the incorporation of different dimensions of social capital and recognizes that communities can have access to more or less of them". ${ }^{28}$

Consequently, from the viewpoint of Woolcock's definition of social capital, an important implication concerns the plight of the poor or poor communities. In order for such groups to progress along the continuum of economic development and social inclusion, he has upheld the thesis that it is onlythrough "the different combinations of bonding, bridging and linking social capital"29 that progress could be realised. By implication, therefore, this thesis suggests that it is in particular the poor who suffer from unequal access to the different dimensions of social capital. $3^{0}$ Whilst it could typically be expected of poor communities to have ample access to the kinds of "close-knit and intensive stock of bonding social capital" - otherwise also referred to as "strong intra-community ties"31 - that they depend on for their everyday survival, 32 the opposite would betrue concerning their access to bridging andlinking social capital. In particular, this makes evident the predicament of poor communities: that they almost as a rule haveweak access to the kinds of "more diffuse and extensive bridging social capital" or extra-community networks

\footnotetext{
${ }^{22}$ Woolcock, "Social Capital and Economic Development," 155-159.

${ }^{23}$ Woolcock, "Social Capital and Economic Development," 159.

${ }^{24}$ Woolcock, "Social Capital and Economic Development," 159.

${ }^{25}$ One attempt at such differentiation drawn upon in this article incorporates the work of Deepa Narayan, another prominent contributor to the debate on social capital at the World Bank. See footnote 20.

${ }^{26}$ Woolcock and Narayan, "Social Capital: Implications for Development," 226; see alsoWoolcock, "The Place of Social Capital," 9; Woolcock, "Social Capital and Economic Development," 155.

${ }^{27}$ Woolcock and Narayan, "Social Capital: Implications for Development," 226.

${ }^{28}$ Woolcock and Narayan, "Social Capital: Implications for Development," 226-227.

${ }^{29}$ Woolcock, "The Place of Social Capital," 11; Woolcock and Narayan, "Social Capital: Implications for Development," 230.

${ }^{30}$ Woolcock, "The Place of Social Capital," 3-4, 11; Woolcock and Narayan, "Social Capital: Implications for Development," $230-233$.

${ }^{31}$ In adopting the notion of "strong intra-community ties" to define the concept of bonding social capital, Woolcock has been strongly influenced by Mark Granovetter's earlier work in which he distinguished between "strong" and "weak" ties in thinking about social networks. As such, "weak ties" also became an appropriate notion for what Woolcock understands by "bridging social capital." See Mark S. Granovetter, "The Strength of Weak Ties," American Journal of Sociology 78, no. 6 (2001): 1360-1380.

${ }^{32}$ Woolcock, "The Place of Social Capital," 10-11; Woolcock and Narayan, "Social Capital: Implications for Development," 230-231; see also Woolcock, "Social Capital and Economic Development," 168-175.
} 
"typically deployed by the non-poor to 'get ahead"; 33 and even worse, that they almost without exception lack access to the kinds of linking social capital or society's vertical connections of "to gain sustained access to formal institutions such as banks, insurance agencies, and the courts". 34

For Woolcock, then, the upside of his thesis would be that in those instances where "the social networks of the poor become more diverse, so too does their welfare". 35 Importantly, however, within this theoretical claim, especially in so far as the life situations of poor communities are concerned, the place and role of bonding social capital should not be under-valued. Instead, it is recognised that strong intra-community ties, or stocks of bonding social capital, in poor communities can be of great benefit to the development aspirations of those communities; that is, however, only to the extent to which such stocks of bonding social capital are complemented over time by the creation of new forms of social capital that enable linkages to non-community members outside those communities. 36

Thus, for Woolcock the decisive point is that too much or too little of either "intensive intracommunity integration" or "extensive extra-community linkages" at any given moment "undermines economic advancement". 37 Accordingly, the clear challenge to social capital theory, research and policy could thereforebeconsidered to be as follows:

(...) to identify the conditions under which the many positive aspects of bonding social capital in poor communities can be harnessed and its integrity retained (and if necessary, its negative aspects dissipated), while simultaneously helping the poor to gain access to formal institutions and a more diverse stock of bridging social capital. ${ }^{8}$

Having reached an important point in Woolcock's overall argument, however, it is necessary to point out that he also cautions against romanticising a social capital approach to development. He cautions that such an approach (or strategy) maybe "fraught with multiple dilemmas", 39 since it may require changes to "social systems that are the product of longstanding cultural traditions or of powerful vested interest". ${ }^{\circ}$ Yet, whilst these dilemmas could in the first place point to the problems of local communities, they also go beyond such problems to take more explicitly into account a larger institutional dimension.

In taking his argument a step further, Woolcock proceeds by adopting the significant idea of "bottom-up" and "top-down dilemmas of development". ${ }^{41}$ Accordingly, bottom-up strategies of social capital formation for development - in which intermediaries such as non-governmental

\footnotetext{
${ }^{33}$ Woolcock, "The Place of Social Capital," 11; see also Woolcock, "Social Capital and Economic Development," 168; Woolcock and Narayan, "Social Capital: Implications for Development," 231-233.

${ }^{34}$ Woolcock, "The Place of Social Capital," 10-11.

${ }^{35}$ Woolcock and Narayan, "Social Capital: Implications for Development," 232.

${ }^{36}$ Woolcock, "Social Capital and Economic Development," 174; see also Woolcock and Narayan, "Social Capital: Implications for Development," 232-233, 242.

${ }^{37}$ Woolcock, "Social Capital and Economic Development," 175.

${ }^{38}$ Woolcock and Narayan, "Social Capital: Implications for Development," 233.

${ }^{39}$ Woolcock and Narayan, "Social Capital: Implications for Development," 233.

${ }^{40}$ Woolcock and Narayan, "Social Capital: Implications for Development," 233.

${ }^{41}$ Woolcock, "Social Capital and Economic Development," 167-182.
} 
organisations, extension services and development agencies may be involved 42 - would obviously be concerned with factors of cultural and political resistance to efforts of positive social capital formation in local communities. 43 However, in Woolcock's theoretical framework this concern alone would not be sufficient, as it should be recognised that "the very capacity of social groups to act in their collective interest depends on the quality of the formal institutions under which they reside" 44 - that is, the internal coherence, credibility and competence of such institutions, and crucially, their external accountability and willingnessto reach out to civil society (and, by implication, local communities). 45

In the light of the above, a likely challenge in any attempt to promote development through strategies of social capital formation in many contexts could be the absence in society's major formal institutions - in particularly state institutions but also firms ${ }^{46}$ - of the necessary credibility, competence and, not least, accountability to its citizens. According to Woolcock, this could be referred to as the "top-down dilemmas of development," 47 which, if not resolved, will leave little if any prospect for existing forms of communal social capital, whether bonding or bridging, to contribute to the long-term sustainable development of local communities. 48

It follows, then, that Woolcock's overall argument could best be associated with what he refers to in his writings as the "synergy view" or perspective on social capital and economic development. 49 According to this view, real progress in terms of the long-term sustainable development of poor local communities could only be achieved where existing and new stocks of bonding, bridging and linking social capital function in a dynamic interactive and complementary relationshiptotheadvantage and inclusion of those communities.

Yet in terms of this synergetic ideal it could be that the objectives of interactive bonding and bridging social capital might be more achievable, whilst the greatest "dilemmas" might lie in finding the ways and means to open up opportunities for complementary linking social capital formation. Yet as these dilemmas shift attention to the prospective and actual agencies or actors involved in achieving the synergetic ideal of complementary social capital formation, Woolcock's own anticipation is that local communities and their leadership, as well as intermediaries such as activists and non-governmental organisations, could realistically be expected to gain access - from the bottom-up and under particular conditions - to society's economic and political institutions of power. $5^{\circ}$ To this extent, he even advances the idea that such actors could "become agents of more general reform" 51 (from the bottom-up) that could lead to greater credibility and accountability, particularly in the case of the state. At the same time, however, whilst emphasising the possibilities of such a bottom-up approach, Woolcock seems

\footnotetext{
${ }^{42}$ Woolcock and Narayan, "Social Capital: Implications for Development," 233.

${ }^{43}$ See Woolcock, "Social Capital and Economic Development," 171-173.

${ }^{44}$ Woolcock and Narayan, "Social Capital: Implications for Development," 234.

45 Woolcock and Narayan, "Social Capital: Implications for Development," 234; see also Woolcock, "Social Capital and Economic Development," 176-178.

${ }^{46}$ Woolcock and Narayan, "Social Capital: Implications for Development," 236.

${ }^{47}$ Woolcock, "Social Capital and Economic Development," 176-178.

${ }^{48}$ See Woolcock and Narayan, "Social Capital: Implications for Development," 234-239.

${ }^{49}$ See Woolcock and Narayan, "Social Capital: Implications for Development," 235-239.

${ }^{50}$ Woolcock, "The Place of Social Capital," 16; cf. Woolcock and Narayan, "Social Capital: Implications for Development," 238.

${ }^{51}$ Woolcock and Narayan, "Social Capital: Implications for Development," 16.
} 
unable to address questions about the factors or conditions that could move (or change) a society's formal institutions of power from the top down, noticeably with reference to the state but including all institutions of power, enabling them to become more responsive to the communities over which they preside. This point is well captured by Woolcock:

Importantly, what is true of state-society relations holds more generally for all forms of "top down" development: any institution with a development agenda must be at once engaged with the communities it seeks to serve and capable of maintaining its own credibility and effectiveness. Such an approach, in turn, begs three important questions: What conditions facilitate the emergence of top-down social relations $5^{2}$ characterized by synergy and integrity? Can some measure of synergy and y be established where prevailing conditions seem inimical to it? If so, how?53

\section{From Social Capital to Religious Social Capital}

Proceeding now to a more specific focus on the nexus between religion and social capital formation, I have found the notion of "religious social capital" a most useful concept.54 The term was coined in more recent academic debates about religion and social capital formation in the United States, 55 but I want to go a step further by appreciating the notion of religious social capital ${ }^{6}$ for its generic and universal value. ${ }^{57}$ Clearly, the basic premise on which this notion is based - namely that there may be enough sociological evidence available today to suggest that religious communities at their best 58 represent social spaces "that may be particularly salient as repositories of social capital" 59 - seems just as valid to the context of the United States of America as to that of South Africa and many other contexts around the world. From a South African point of view in particular, it is useful to recall here at some length part of a discussion of the empirical

\footnotetext{
${ }^{52}$ Read: "linking social capital."

${ }^{53}$ Woolcock, "Social Capital and Economic Development," 178.

${ }^{54}$ I should emphasise that this has been a rather recent discovery in my own conceptual exploration of the nexus between religion and social capital, which I am adopting for the first time in this article.

${ }^{55}$ See the various contributions in Corwin Smidt (ed.), Religion as Social Capital: Producing the Common Good (Waco, tx: Baylor University Press 2003); also Joanna Maselko, Cayce Hughes and Rose Cheney, "Religious Social Capital: Its Measurement and Utility in the Study of the Social Determinants of Health," Social Science \& Medicine 73, no. 5 (2011): 759- 767; Heidi Rolland Unruh and Ronald J. Sider, Saving Souls, Serving Society: Understanding the Faith Factor in Church-Based Social Ministry (Oxford: Oxford University Press, 2005), 218-238; cf. Chris Baker and Jonathan Miles-Watson, "Faith and Traditional Capitals: Defining the Public Scope of Spiritual and Religious Capital - A Literature Review,"Implicit Religion 13, no. 1 (2010): 31-33.

${ }^{56}$ I want to acknowledge Heidi Rolland Unruh and Ronald Sider's application and use of the notion of "congregational social capital" in the very specific context of a Christian evangelical debate in the usa as a noticeable variant capturing the same idea as religious social capital does. See Unruh and Sider, Saving Souls, Serving Society, 219-232.

${ }^{57}$ By appreciating the notion of religious social capital, I am not suggesting that there is no other valuable literature and conceptual innovation within the academic debate on religion and social capital. To the contrary, an ever-growing corpus of international literature within this debate can be acknowledged that does not necessarily adopt or use the notion of religious social capital, but offers arguments and perspectives similar to those found under the rubric of religious social capital. At the same time, however, I find the notion of religious social capital and the smaller, more manageable corpus of literature related to it particularly valuable for the line of argumentation that I am developing in this article.

58 "At their best" should be regarded as an important qualification here. As I will argue, along with the relevant literature later in this section, there may also be important limitations connected to the notion and actual phenomenon of religious social capital.

${ }^{59}$ Maselko et al., "Religious Social Capital," 760; see in further support of this observation John A. Coleman, "Religious Social Capital: Its Nature, Social Location, and Limits," in Religion as Social Capital: Producing the Common Good, ed. Corwin Smidt (Waco, tx: Baylor University Press 2003), 33; Corwin Smidt, "Religion, Social Capital and Democratic Life: Concluding Thoughts," in Religion as Social Capital: Producing the Common Good, ed. Corwin Smidt (Waco, tx: Baylor University Press 2003), 216-222; Unruh and Sider, "Social Capital and Spiritual Capital," 219-232.
} 
results emanating from the project on "Faith-based Organisations, Social Capital and Development" 60 that preceded the project work on which this articleis based:

In more overt social capital language, the dense and widespread location of churches in an important way suggests that they could be a significant constituting source of social capital networks through which the most poor and deprived may be reached and the collective problems in those communities be addressed in a concerted and self-reliant manner by the people themselves. In this regard, furthermore, it has been shown by the ... results how churches are especially well represented in those areas of the communities where people are suffering mostunder particularsocial problems.

Yet, more than any other notion of social capital, it is to the notion of social trust that various aspects of the research results could be related explicitly ... [W]e have seen from the results that the churches command the respect and appreciation of many people. For them churches are indispensable social role players that should be involved in the social problems of their community and intervene in those areas where services are crucially needed. They also do not bear out the view that the churches do not care for the poor and, in fact, present the churches with a strong mandate to engage in strategic activities of social capital formation, to build relationships of co-operation themselves, as well as with government and the ngo sector ...

Proceeding beyond the notion of social trust to more tangible manifestations of social capital formation and community action, the ... results also suggest that churches in the researched communities act as generators of voluntary outreach, caring initiatives and different modes of social needs. In particular, it appears from the results that such concrete actions are the greatest and most successful in areas where people are more exposed to the various social problems than in areas wherethe problemsareless prevalent. ${ }^{61}$

Following on the above, it could be observed that those scholars who want to advance the debate on religion and social capital under the more specific rubric of religious social capital do so with the intention of taking the debate to a deeper level of inquiry. Thus, beyond an appreciation of religion as a noticeable generator of social capital among the different associations in civil society, they are more specifically concerned with the question of the extent to which there may be "something distinctive"62 about those formations of social capital that are very specifically bound to religious life 63 and serve "to differentiate it from other kinds of social capital." 64 Accordingly, they even more specifically want to inquire whether "the nature of the social capital generated within religious contexts" 65 could be considered as "qualitatively different from that generated outside its domain", ${ }^{66}$ that is, in contradistinction to the thesis or

\footnotetext{
${ }^{60}$ See footnotes 1 and 4.

${ }^{61}$ Swart, "Churches as a Stock of Social Capital," 368-369.

${ }^{62}$ Smidt, "Religion, Social Capital and Democratic Life," 216.

${ }^{63}$ Smidt, "Religion, Social Capital and Democratic Life," 211.

${ }^{64}$ Smidt, "Religion, Social Capital and Democratic Life," 216; see also Corwin Smidt, "Introduction," in Religion as Social Capital:

Producing the Common Good (Waco, tx: Baylor University Press, 2003) 3; Coleman, "Religious Social Capital," 33-34.

${ }^{65}$ Smidt, "Religion, Social Capital and Democratic Life," 216.

${ }^{66}$ Smidt, "Religion, Social Capital and Democratic Life," 216.
} 
possibility that all social capital should be regarded as "basically similar in nature, regardless of its origins." 67

I am not in a position here to elaborate in detail on the arguments and perspectives that have emanated as a result of the more specific focus so far in the literature on the notion of religious social capital. At the same time, though, I want to briefly draw upon two main lines of argumentation that have emerged from the discussions that I find especially valuable for the purpose of developing my own argument in this article.

Firstly, of importance is certainly one dominant line of argumentation that, in the words of one of the authors (Corwin Smidt), there are indeed "particular qualities about religious social capital that help to differentiate it from other forms of social capital and that serve to make it distinctive in nature, whether qualitatively or quantitatively." ${ }^{88}$ Smidt has found it possible to make such a claim on the basis of the various contributions to a study that very pertinently wanted to address the question of religious social capital's similarity to, or distinctiveness from, the social capital generated through other forms of association. ${ }^{69}$ Based on the contributions to the volume Religion as Social Capital (11 essays in total),70 Smidt concluded that it was possible to identify five ways in which religious social capital, at least in the United States, may be distinguished from other forms of social capital:

- in terms of its "quantity": the wayin which social capital generated through religious means exceeds levels of social capital generated through other means in society; ${ }^{71}$

- in terms of "durability": the way in which religious motivation or the standard employed by religious peopleon thebasis of theirvalues, commitments and calling sustain efforts of social capital formation; 72

- in terms of its "range": the way in which religious social capital reaches people across a diverse spectrum of backgrounds that noticeably includes the "voiceless" and marginalised;73

- in terms of its "capacity to nourish social capital": the way in which religiously endowed social capital shows an ability - not least through its command of transcendent values - to foster stronger norms of reciprocity than isoftenthecase withsocial capitalgeneratedfrommoresecularsources;74

— in terms of its "capacity building ability": the way in which religious social capitaltends todistribute opportunities for skills and confidence building that may often not be available to citizens (noticeably resource-poor citizens) within the wider society.75

Secondly, no less important is the line of argumentation put forward by some authors that there may be limits to what religious social capital could offer as a social phenomenon. While they by and large want to go along in celebrating the special qualities that religious social capital may hold, for the authors of the

\footnotetext{
${ }^{67}$ Smidt, "Religion, Social Capital and Democratic Life," 216; cf. Coleman, "Religious Social Capital," 33-34.

${ }^{68}$ Smidt, "Religion, Social Capital and Democratic Life," 216.

${ }^{69}$ Smidt, "Introduction," 3.

${ }^{70}$ See the various essays in Smidt, Religion as Social Capital.

${ }^{71}$ Smidt, "Religion, Social Capital and Democratic Life," 217.

72 Smidt, "Religion, Social Capital and Democratic Life," 217.

73 Smidt, "Religion, Social Capital and Democratic Life," 217.

${ }^{74}$ Smidt, "Religion, Social Capital and Democratic Life," $217-218$.

${ }^{75}$ Smidt, "Religion, Social Capital and Democratic Life," 218. For similar arguments advanced elsewhere, see Chapter 11 on "Social and Spiritual Capital," in Unruh and Sider, Saving Souls, Serving Society, 218-238.
} 
"limits of religious social capital" perspective such celebration needs to be relativised by a consideration of the essential or primary purpose of religious organisations such as churches. These authors have found significant support for their own line of argumentation in an observation made by the well-known practical theologian, Don Browning: "salvation" and not the increase of social capital should be regarded as "the primary purpose of churches and their narratives." ${ }^{\prime 6}$ Christianity, this argument continues, tells the story of how God's creation and grace empower its followers to live an ethic of equal regard and self-sacrifice in expectation that God's grace will sustain them. For this reason, it could be argued that Christians do not in the first place live the Christian life to produce social capital, but instead that "increased social capital is a long-term, secondary consequence of Christian life".77

For one of the authors adopting the "limits of religious social capital" perspective (John Coleman), thinking along the lines of Browning's argumentation therefore even has to persuade those involved in the religion and social capital debate to seriously consider the possibility of employing "other metaphors besides 'social capital"' 78 to do justice to the essential purpose and rationale for the existence of religious organisations such as churches. For him, this could be considered as necessary because of "the economic, rational-choice, and market models" 79 implicit in the metaphor of social capital, which "systematically erodes all possibility of direct qualitative comparison." 80

Yet, beyond such problematisation of conceptual comparison, one nevertheless encounters within the "limits of religious social capital" perspective an acceptance that the notion of religious social capital remains a worthwhile concept to capture a particular reality. So, for instance, from the point of their empirical interest in the social ministry of evangelical churches in the United States of America, Heidi Rolland Unruh and Ronald Sider have been arguing that the concept of congregational social capital offers a way of describing such churches' "inherent potential for coordinating coporate social action"; 81 that is, in morespecificterms:

(...) for encouraging volunteerism and other forms of civic engagement by individual members; for giving resource-poor persons access to resources of the congregation and its extended social networks; and for connecting groups in the community with one another and with a unifying, hopeful vision. ${ }^{82}$

However, even by connecting strongly to the idea of social capital as a "long-term, secondary consequence" of religious life, Unruh and Sider have insisted that none of the identified benefits deriving from evangelical social life could be regarded as the primary function of those churches. For them, the main reason why members of a particular church "form a trusting,

\footnotetext{
${ }^{76}$ Browning, quoted in Coleman, "Religious Social Capital," 45; Unruh and Sider, Saving Souls, Serving Society, 238.

${ }^{77}$ Browning, quoted in Coleman, "Religious Social Capital," 45; Unruh and Sider, Saving Souls, Serving Society, 238.

${ }^{78}$ Coleman, "Religious Social Capital," 45.

${ }^{79}$ Coleman, "Religious Social Capital," 44.

${ }^{80}$ Coleman, "Religious Social Capital," 45.

${ }^{81}$ Unruh and Sider, Saving Souls, Serving Society, 225.

${ }^{82}$ Unruh and Sider, Saving Souls, Serving Society, 225.
} 
norm-laden social network" 83 could not be related to any one of the above-mentioned social benefits. Rather, the formation of such networks could primarily be attributed to people's inclination to associate in order to "meet needs that are uniquely met in a religious group, such as spiritual meaning, loveand identity." 84

It is from the point of departure of such a primary inclination, then, that one could perceive thepossibility of outward-orientated congregational or religious social capital arising - but as the long-term, secondary consequence of this primary inclination. Yet, within the frame of such a possibility, authors of the "limits of religious social capital" perspective qualify that there maystill be important limits to what could in actual fact become possible. Amongst a range of possible impeding factors or caveats identified, such limitation may involve the rather natural tendency among religious people to experience the sacred as "rooted in privateconcerns and spirituality." 85 But at the same time, such limitation could also be founded in the equally natural inclination of religious units such as congregations to more often than not "turn their energies" to addressing the needs and interest of their own group rather than looking outward to the larger community. ${ }^{86}$ As a result, the existing stocks of social capital of such groups may remain dormant, coupled with an inability or simply lack of interest among members of such groups "to invest or multiply their social capital into the larger society." ${ }^{7}$ For them, it may be sufficient just to "meet short-term emergency needs among their own members" and assist those on the outside who may be working to keep their own churches alive. ${ }^{88}$ But also equally probable, they may not see a need to engage in community programmes, as "they believe the church is best suited to make a social contribution through individual conversions." 89

In drawing the discussion in this section to a close, I want to be sensitive to the fact that I have relied on a corpus of literature that reflects a context far removed from my own South African context and even more so the African traditional religious setting on which the larger project work from which this article derives intended to focus. $9^{\circ}$ Yet, having engaged in a deeper exploration of the argumentation around the notion of religious social capital, I see no need to at this point deviate from my initial view about the generic and universal value of religious social capital as a concept.

As I have in fact already suggested in the course of the discussion, there seems to be much theoretical and conceptual value for a South African research agenda in the thematic field of religion and social capital ${ }^{1}$ to at least relate to the broad lines of argumentation that have emanated from the conceptual focus on religious social capital in the usa. In making this evaluation, there indeed seems to be significant scope to also once again consider the findings of

\footnotetext{
${ }^{83}$ Unruh and Sider, Saving Souls, Serving Society, 225.

${ }^{84}$ Unruh and Sider, Saving Souls, Serving Society, 225.

${ }^{85}$ Coleman, "Religious Social Capital," 45-46.

${ }^{86}$ Coleman, "Religious Social Capital," 38.

${ }^{87}$ Coleman, "Religious Social Capital," 37-38, 46; see also Unruh and Sider, Saving Souls, Serving Society, $232-235$.

${ }^{88}$ Coleman, "Religious Social Capital," 38.

${ }^{89}$ Unruh and Sider, Saving Souls, Serving Society, 234.

${ }^{90}$ See footnote 5 .

${ }^{91}$ I made a claim to having such an agenda in Swart, "Religion and Social Capital Research in South Africa," based on the project work described in this article.
} 
the already stated previous South African project.92 Since it is in those findings, quoted extensively at the beginning of this section, 93 that one could firstly recognise elements of the distinguishable features of religious social capital that have been identified in the American focus. But secondly, however, it is in those same findings that one could also find evidence of the "limits to religious social capital" perspective that in many instances qualifies local churches or congregations' actual social capital performance in the South African context:

In addition, it also became clear on the basis of the socio-empirical results that a significant "grey area" remained with regard to the actual participation of the churches in addressing the identified problems. Thus the results suggested that no clear correlation exists between the different sets of results of people's involvement and that of the churches themselves ... Particularly in those communities where historic inequalities have by and large been maintained, there was no evidence that the churches were in any way involved in strategic activities of social capital formation aimed at the building of relationships across the divides and the kinds of active redress spelled out ... At best, where churches might actually be involved, their activities of charity and relief assumed some kind of superficial social capital formation. 94

\section{Towards Addressing the Missing Element of Religious Ritual}

On the basis of the conceptual framework that has steered me to move from a theoretical perspective on social capital to a more pertinent focus on the notion of religious social capital, I find it rather astounding that the collective international research focus on religion and social capital formation to date has completely ignored the factor of "religious ritual". Indeed, with the exception of a single publication by two researchers who have contributed to the project work that I have alluded to in this article (as I will point out below), I could find no evidence of research that has attempted to address this "missing element". ${ }^{55}$ Furthermore, I find this neglect astounding on the grounds of one very pertinent insight: the extent to which the phenomenon of ritual ought to be recognised as "a critical component of religion", 96 that is, to the extent that one could well claim with scholars of religious ritual that "it is the enduring framework of religious ritual" that "defines the sacred" within any community through the symbols and practices that it actualises. 97 In the equally confirmative words of the Dutch ritual scholar Gerard Lukken, it in fact becomes is precisely rituals that awaken religious experience"; in short, "ritual is the language that awaken religious experience"; in short, "ritual is the language that pre-eminently fits religion, and conversely, ritual is first and foremost a religious phenomenon." 98

\footnotetext{
${ }^{92}$ See footnotes 1,4 and 60.

${ }^{93}$ I.e., the quote referenced in footnote 61.

${ }^{94}$ Swart, "Religion and Social Capital Research in South Africa," 113-114; see also Swart, "Churches as a Stock of Social Capital," 369-370.

${ }_{95}$ This concerns the full spectrum of the literature referred to in footnote 57.

${ }^{96}$ Nancy C. Ring, Kathleen S. Nash, Mary N. MacDonald and Fred Glennon, Introduction to the Study of Religion (Maryknoll, ny: Orbis, 2012), 97; cf. Gerard Lukken, "No Life Without Rituals," in Per Visibilia Ad Invisibilia: Anthropological, Theological and Semiotic Studies on the Liturgy and the Sacraments, eds. Louis van Tongeren and Charles Caspers (Kampen: Kok Pharos, 1994), 110; Richard Sosis and Candace Alcorta, "Signaling, Solidarity, and the Sacred: The Evolution of Religious Behavior," Evolutionary Anthropology 12, no. 6 (2003), 265; Donald Swenson, Society, Spirituality, and the Sacred: A Social Scientific Introduction (Peterborough, Ont.; New York, ny: Broadview Press, 1999), 183.

${ }^{97}$ Sosis and Alcorta, "Signaling," 265.

${ }^{98}$ Lukken, "No Life without Rituals," 110.
} 
My argument so far in this section emphasises the point that the prevailing neglect of the ritual factor crucially needs to be addressed in order to deepen our understanding of the phenomenon of religious social capital. When this is recognised as a critical component of religious experience and practice, a research agenda is clearly called for that will concern itself anew with questions about the actual role and place of the "ritual factor" in religious social capital formation. But even more specifically in the light of the exploration in this article, it should be considered as a most worthwhile undertaking to bring the ritual element to the centre of a research agenda aimed at deepening understanding of the two lines of argumentation on the qualitative nature but also the limits of religious social capital. As such, whereas there may be solid grounds today for accepting both lines of argumentation, it is my contention that considerable scope remains to explore questions about the manner and extent to which the ritual element may in fact be a (if not the) primary source that in certain cases grants religious social capital its particular qualities and in other cases inhibits that qualitative potential. Indeed, where the focus would, for instance, be on more specifically considering evidence of the limits of the religious social capital perspective, one could ask what other element besides the ritual element may be responsible for granting particular religious communities those inward-looking qualities and self-understanding that can be regarded as detrimental to more idealised forms of social capital formation?

I do not consider it as my task in this article to come up with a more sharply focused definition or discussion of religious ritual. My basic intention within the conceptual framework that I have set out is rather to simply put forward the case for ritual as a crucial missing element in the scholarly exploration to date of religious social capital as a theoretical and empirically founded concept. From this vantage point, however, I conclude this section with two significant "pointers" emanating from my review of the relevant literature in starting to make more pointedly the conceptual link between the exploration of a more generic social capital conceptual framework (with its more specific distinctions between bonding, bridging and linking social capital) and the notion of religious social capital.

With respect to my first pointer, even if it falls outside the parameters of the theoretical exploration in this article, I do not want to be ignorant of the fact that a more in-depth exploration of the existing scholarship on religious ritual may not only be helpful but also necessary for undertaking the conceptual work on the connection between ritual and religious social capital formation. While it should be just as important to acknowledge the neglect of scholars of religious ritual to include the concept of social capital in their own theorising, besides my own critical stand against the neglect of the ritual factor in existing religion and social capital research, this does not mean that one may not find theoretical insights and a conceptual language in their theoretical work on religious ritual helpful. In this respect, I want to uphold as a single case in point a chapter on the study of religious ritual written some years ago by the Canadian sociologist of religion, Donald Swenson, as part of his larger theoretical investigation on the interface between society, spirituality and the sacred. 99

\footnotetext{
${ }^{99}$ Swenson, Society, Spirituality, and the Sacred. I am referring here to Chapter 7, "The Symbolic Dilemma: The Study of Ritual," $183-$ 208.
} 
While it would be impossible within the limited space at my disposal to do justice to the whole of Swenson's discussion, of particular significance here is the part of his discussion where he goes to great lengths to provide his readers with both a "substantive" and "functional" definition of ritual. ${ }^{100}$ In accordance with this rather familiar conceptual distinction applied in religious studies scholarship to define the essential nature of religion and the effects it has on people and the social order, respectively, ${ }^{101}$ for Swenson, firstly, the theoretical perspectives of renowned scholars such as Emile Durkheim, William Robertson Smith and Clifford Geertz are regarded as valuable in informing a substantive definition of religious ritual. ${ }^{102}$ And it is on the basis of their contributions that he then offers his own attempt towards a substantive definition, which he formulates as follows:

Ritual is repeated consecrated (sacred) behaviour that is a symbolic expression of the moods and motivations of religious participants and unseen powers. Ritual forms a bond of friendship, community, and unity with the believer and her/his god. Finally, ritual transports the participant in to another world (the world above) wherein there is peace and harmony. ${ }^{103}$

Secondly, by reiterating the point that a functional definition of ritual in turn explains "what ritual does", that is, the function it has for the individual believer and for the social group or society of which he/sheisapart, ${ }^{104}$ Swenson identifies eight functions of ritual in the literature. In what could thus be regarded as an attempt by Swenson to provide some kind of a synthesis of perspectives from the existing scholarship on ritual, these eight functions are summarised as follows:

— Ritual as "remembering" - i.e., the way in which ritual reminds both individuals and social groups about their heritage and past; ${ }^{105}$

— Ritual as "social bonding" - i.e., the way in which ritual functions to bond persons together, increase levels of social cohesion and strengthen group solidarity; 106

- Ritual as "regulating moral behaviour" - i.e., the way in which ritual regulates the behaviour of societal members and in the process maintains moral order; 107

- Ritual as "socialization and changes in social statutes" - i.e., the way in which ritual enables the transition ofanindividualfromonestatustoanother(for example, marriage);108

- Ritual as "psychological development" - i.e., the wayin which ritual facilitates a sense of psychological wellbeing amongst individuals and groups; 109

— Ritual as "bonding to nature" 110 - i.e. the way in which ritual integrates people with nature;":11

\footnotetext{
${ }^{100}$ Swenson, Society, Spirituality, and the Sacred, 184-198.

${ }^{101}$ Swenson, Society, Spirituality, and the Sacred, 184.

${ }^{102}$ Swenson, Society, Spirituality, and the Sacred, 184-185.

${ }^{103}$ Swenson, Society, Spirituality, and the Sacred, 185.

${ }^{104}$ Swenson, Society, Spirituality, and the Sacred, 186.

${ }^{105}$ Swenson, Society, Spirituality, and the Sacred, 187-188.

${ }^{106}$ Swenson, Society, Spirituality, and the Sacred, 188-190. It could be noted here how Swenson relies on the classic works of Smith and Durkheim in support of his identification of this function. He shows how they (Smith and Durkheim) held similar opinions about the way in which the bonding element established between believers and their gods through ritual practice (such as acts of worship) effectively leads to human bonding. Smith referred to the way in which ritual "renewed the bonds of family, social and national obligation" and Durkheim to the way in which ritual strengthens "the bonds attaching the individual to the society of which he is a member" (see pp. 188-189).

${ }^{107}$ Swenson, Society, Spirituality, and the Sacred, 190-191.

${ }^{108}$ Swenson, Society, Spirituality, and the Sacred, 191-193.

${ }^{109}$ Swenson, Society, Spirituality, and the Sacred, 193-194.
} 
— Ritualas “empowerment"-i.e., the wayin which ritual assistsindividuals andwholegroupsinfeeling stronger,lessdisaffectedandmorereadytoserve others; ${ }^{112}$

- Ritual as "evoking the nefarious" - i.e., the way in which at least certain kinds of ritual function to bring harm, hurt and even death to other people. ${ }^{113}$

Importantly, then, whilst Swenson's work on religious ritual shows no evidence of any direct interest in or reliance on the concept of social capital, the above brief outline of his attempt at defining ritual nevertheless reflects a striking overlap with at least one element of the language of social capital explored in the first section of this article. In this respect, I could even go so far as to uphold Swenson's contribution as a meaningful case in point of how a new focus on ritual may offer important new directions for ongoing research on religious social capital. Even if this restricts one, in the case of Swenson's theorising, to the notion of "bonding" social capital formation, ${ }^{114}$ I find the possibility of a newdirectionalreadyimplicitinhissubstantivedefinition and the way in which theline of theorising in this definition may broaden the religious social capital discourseinto a concept that is increasingly coming into vogue in the international debates about social capital, namely "spiritual capital". ${ }^{115}$ In addition to this, I also find several possibilities for a new direction makes a strong case for functional understandings of ritual that in the respective cases (i) reverberate with the conceptual understanding of bonding social capital articulated in the first section of this article, ${ }^{116}$ (ii) extend the meaning and significance of religious social capital to an understanding that has ecological significance, ${ }^{117}$ and (iii) in more than one instance propose functions that may have relevance for and inform the argument about the qualitative nature of religious social capital highlighted in the second section of this article. ${ }^{118}$

Finally, my second pointer relates back to the observation at the beginning of this section regarding what I have found to be the exception of a single publication that attempted to address the missing element of religious ritual within the ambit of religion and social capital research. Having also alluded to the fact that this was a publication from my own circle of coinvestigators, ${ }^{119}$ I am here referring to the research by two scholars of homiletics and liturgical

\footnotetext{
${ }^{110}$ Swenson also refers to this aspect as the "ecological function of ritual." Swenson, Society, Spirituality, and the Sacred, 194.

${ }^{111}$ Swenson, Society, Spirituality, and the Sacred, 194-195.

${ }^{112}$ Swenson, Society, Spirituality, and the Sacred, 195-196.

113 Swenson, Society, Spirituality, and the Sacred, 196-197.

${ }^{114}$ One could for instance at this point observe how the words "bond" and "bonding" are three times explicitly used by Svenson in his respective definitions.

${ }^{115}$ My line of argumentation here very much follows Gerrie ter Haar's recent incorporation of the concept of spiritual capital in the international debate about religion and development. By alluding to spiritual capital as "a sub-set of social capital," Ter Haar has argued that spiritual capital could be regarded as a form of capital that derives from believers' connection with "an invisible world inhabited by spiritual entities in the form of gods, deities, personalised spirits and impersonal spiritual forces" - i.e. the same world that in Swenson's substantive definition of ritual constitutes the sphere where bonds of friendship, community and unity with believers and their gods are formed. As a direct result of such connection, for Ter Haar "spiritual capital" could therefore be defined as "people's ability to access resources believed to reside in an invisible world, which can be mobilised for the common good through forms of active engagement with them." Gerrie ter Haar, "Religion and Development: Introducing a New Debate," in Religion and Development: Ways of Transforming the World, ed. Gerrie ter Haar (New York, ny: Columbia University Press, 2011), 14, 20.

${ }^{116} \mathrm{I}$ am thus drawing a clear comparison here between such understanding of social capital and the social bonding function of ritual identified by Swenson. See also footnote 106.

117 See footnote 111 .

${ }^{118} \mathrm{I}$ am here in particular referring to the identifications that point to religious ritual's functions in regulating moral behaviour and empowering individuals and groups.

${ }^{119}$ See also the recognition and discussion of this research in Swart, "Religion and Social Capital Research in South Africa," $115-117$.
} 
studies, Cas Wepener and Johan Cilliers, which significantly formed part of the project on "Faithbased Organisations, Social Capital and Development”. ${ }^{20}$

As stated in the published chapter on their research, ${ }^{121}$ Wepener and Cilliers proceeded with the clear aim to explore "more closely the potential links between the performance of religious rituals and the generation of social capital, especially in societal contexts of poverty". ${ }^{122}$ Accordingly, this necessarily became an undertaking in which these two researchers combined theoretical and empirical components that could be appreciated for the following reasons relevant to this article:

- The way in which they adopted the theoretical and conceptual framework of bonding, bridging and linking social capital; 123

- The way in which they complemented the aforementioned framework by adding a theoretical perspective based on the empirical work of Nancy Ammerman; 124

- The way in which they defined the meaning of poverty as entailing the absence of social capital; ${ }^{125}$

- The way in which they generated empirical data on the ritual practices of two Reformed congregations from diverse socio-demographic backgrounds in a particular local setting (the South African town of Paarl)through ethnographic fieldwork; ${ }^{126}$

- The way in which they used the method of ritual criticism in conjunction with particular theoretical perspectives on ritual (Gerard Lukken's and Ronald Grimes' respective identifications of "dimensions" and "qualities" of ritual) to analyse and interpret the collected data;127

— The way in which they integrated all the above-mentioned elements to meet the aim of their research.

I find good grounds on the basis of all these elements to uphold Wepener and Cilliers's contribution as exemplary of the way that the missing element of religious ritual could and should start to be addressed. By drawing in an interdisciplinary way on methods from the field of liturgical studies and the broader social sciences, and in an equally interdisciplinary way on existing theoretical work on the issues of ritual, social capital formation and not least religious social capital formation, they present insights that could well be related to both lines of argumentation on religious social capital highlighted in this article. In support of the "qualitative" line of argumentation, they present us with empirically founded evidence of how

\footnotetext{
${ }^{120}$ See footnotes 1,4 and 60 .

${ }^{121}$ It should be noted that this chapter is a revised version of a text that was first published in International Journal of Practical Theology 11, no. 1 (2007): 39-55 under the title "Ritual and the Generation of Social Capital in Contexts of Poverty: A South African Exploration."

${ }^{122}$ Cas Wepener and Johan Cilliers, "Ritual and the Generation of Social Capital in Contexts of Poverty," in Religion and Social Development in Post-Apartheid South Africa: Perspectives for Critical Engagement, eds. Ignatius Swart, Hermann Rocher, Sulina Green and Johannes Erasmus (Stellenbosch: sun Press, 2010), 417.

${ }^{123}$ Wepener and Cilliers, "Ritual and the Generation of Social Capital," 417-419.

124 Wepener and Cilliers, "Ritual and the Generation of Social Capital," 418-420, found particularly valuable Ammerman's identification of three modes of social capital formation to which congregations in the usa were contributing. They are: - Social capital of association, involving the creation of a sense of belonging and relationships of trust; - Civil capital of communication and organisational skill; and - Material infrastructure and sources, for example, spaces of gathering.

${ }^{125}$ Wepener and Cilliers, "Ritual and the Generation of Social Capital," 419-420.

${ }^{126}$ Wepener and Cilliers, "Ritual and the Generation of Social Capital," 421.

${ }^{127}$ Wepener and Cilliers, "Ritual and the Generation of Social Capital," 422, 428.
} 
the ritual practices of the two congregations they studied became spaces for various kinds of "bonding" and even "bridging" social capital formation. This, amongst other things but to different degrees, entails the way in which hospitality is shown to strangers; identity and group formation/cohesion is strengthened; meals are shared with less privileged congregational members; mechanisms of collective and individual coping as well as bonding and bridging interactions between congregational members are enhanced, especially through intercessory praying activities; performance, participatory and oratory skills are developed through different liturgical practices; and opportunities for information sharing and symbolic action are created that inspire broader actions directed towards poverty alleviation in the immediate communities. ${ }^{128}$

At the same time, however, Wepener and Cilliers are, in line with the "limits of religious social capital" perspective, also mindful of the fact that their results showed no evidence of expressions of linking social capital emanating from the ritual activity of the two congregations. If this would have been the case, they argue, there would be evidence of a new ethos and mode of action that would confront "structures and constellations of power" and work "in collaboration with other relevant agencies towards a real transformation of society in terms of equity and justice." 129 For them, therefore, it would be in this area of addressing the missing dimension of "linking" social capital that the need for ongoing research and innovation could be considered as being of paramount important. In theirconcluding words:

The discussion ... has made it clear that linking capital and its role regarding real transformation is still largely a missing dimension in the rituals. We have already made suggestions about the role that preaching can play in this respect, but the other elements of liturgy should also beenriched to attend to the linking dimension of social capital. This is, of course, easier said than done and it is an area that needs further research ... The ability to facilitate the participation and distribution of power is one of the most important skills that church leaders ministering in contexts of poverty should acquire. This kind of leadership will help to develop the liturgy as an open space, a space where silent voices are heard, where the truth in all its facets is spoken, where rich and poor are confronted by one another; thus a space that facilitates real transformation. ${ }^{130}$

\section{Conclusion}

This discussion has ultimately brought me to the point where I presented the case of religious ritual as a consistently missing element in the contemporary international research focus on religion and social capital formation. I alluded to the fact that there is much to be discovered in terms of a research agenda that would strive to address this neglect. From a standpoint where ritual would be recognised as a critical component of religious experience and practice, my limited exploration pointed to the potential of a theoretically and empirically founded research undertaking that would seek to explore, in a more concerted and profound way, the connections between the different elements of the conceptual framework in this article: social capital, religious social capital and religious ritual. At the very least, my own exploration could be seen as

\footnotetext{
${ }^{128}$ Wepener and Cilliers, "Ritual and the Generation of Social Capital," 422-426.

${ }^{129}$ Wepener and Cilliers, "Ritual and the Generation of Social Capital," 419.

${ }^{130}$ Wepener and Cilliers, "Ritual and the Generation of Social Capital,"426.
} 
a modest beginning towards achieving this end. This could firstly be considered in the way that the discussion pointed rather assertively to a conceptual and empirically founded understanding of religious ritual as a noteworthy, if not central, element in the formation of bonding and even bridging forms of religious social capital. But it could, secondly, also be considered in the way that the discussion on religious ritual provided little grounds for bringing the notion of linking social capital into the conceptual framework, except for pointing to an empirically founded perspective on the absence of this form of social capital formation in the wake of the ritual practice in a particular religious setting. 


\section{Bibliography}

Baker, Chris, and Jonathan Miles-Watson. "Faith and Traditional Capitals: Defining the Public Scope of Spiritual and Religious Capital - A Literature Review." Implicit Religion 13, no. 1 (2010): 17-69.

Bebbington, Anthony, Scott Guggenheim, Elizabeth Olson, and Michael Woolcock. "Exploring Social Capital Debates at the World Bank." The Journal of Development Studies 40, no. 5 (2004): 33-64.

Cilliers, Johan, and Cas Wepener. "Ritual and the Generation of Social Capital in Contexts of Poverty: A South African Exploration.” International Journal of Practical Theology 11, no. 1 (2007): 39-55.

Coleman, John A. "Religious Social Capital: Its Nature, Social Location, and Limits." Pages 33-47 in Religion as Social Capital: Producing the Common Good. Edited by Corwin Smidt. Waco, tx: Baylor University Press, 2003.

Field,John. Social Capital.London: Routledge, 2003.

Granovetter, Mark S. "The Strength of Weak Ties." American Journal of Sociology 78, no. 6 (2001): 1360-1380.

Lukken, Gerard. "No Life Without Rituals." Pages 88-117 in Per Visibilia Ad Invisibilia: Anthropological, Theological and Semiotic Studies on the Liturgy and the Sacraments. Edited by Louis van Tongeren and Charles Caspers. Kampen: Kok Pharos, 1994.

Maselko, Joanna, Cayce Hughes, and Rose Cheney. "Religious Social Capital: Its Measurement and Utility in the Study of the Social Determinants of Health." Social Science \& Medicine 73, no. 5 (2011): $759-767$.

Ring, Nancy C., Kathleen S. Nash, Mary N. MacDonald, and Fred Glennon. Introduction to the Study of Religion. Maryknoll, ny: Orbis, 2012.

Smidt, Corwin, ed. Religion as Social Capital: Producing the Common Good. Waco, tx: Baylor University Press, 2003.

Smidt, Corwin. "Introduction." Pages 1-18 in Religion as Social Capital: Producing the Common Good. Edited by Corwin Smidt. Waco, tx: Baylor University Press, 2003.

Smidt, Corwin. "Religion, Social Capital and Democratic Life: Concluding Thoughts." Pages 211222 in Religion as Social Capital: Producing the Common Good. Edited by Corwin Smidt. Waco, tx: Baylor University Press, 2003.

Smith, Mark K. "Social Capital." The Encyclopedia of Informal Education. Online: http:// infed.org/mobi/social-capital/,2000-2009.

Sosis, Richard, and Candace Alcorta. "Signaling, Solidarity, and the Sacred: The Evolution of Religious Behavior." Evolutionary Anthropology 12, no. 6 (2003): 264-274.

Swart, Ignatius. "Networks and Partnerships for Social Justice? The Pragmatic Turn in the Religious Social Development Debate in South Africa." r\&t 12, no. 1 (2005): $20-47$.

Swart, Ignatius. "Churches as a Stock of Social Capital for Promoting Social Development in Western Cape Communities.” Journal of Religion in Africa 36, no.3-4 (2006): 346-378

Swart, Ignatius. "Religion and Social Capital Research in South Africa: Mapping an Agenda in Progress." Pages 98-121 in Religion and Social Problems. Edited by Titus Hjelm. Routledge Advances in Sociology. New York, ny: Routledge, 2011.

Swart, Ignatius. "Transforming Social Welfare? The Religious Discourse on Social Development in Post-Apartheid South Africa." Pages 65-93 in Welfare, Religion and Gender in Post-

\section{http://repository.uwc.ac.za}


Apartheid South Africa: Constructing a South-North Dialogue. Edited by Ignatius Swart, Amanda Gouws, Per Pettersson, Johannes Erasmus, and Frouwien Bosman. Stellenbosch: sun Press, 2012.

Swart, Ignatius, Hermann Rocher, Sulina Green, and Johannes Erasmus, eds. Religion and Social Development in Post-Apartheid South Africa: Perspectives for Critical Engagement. Stellenbosch: sun Press, 2010.

Swart, Ignatius, Hermann Rocher, Sulina Green, and Johannes Erasmus. "Introduction." Pages 1-12 in Religion and Social Development in Post-Apartheid South Africa. Edited by Ignatius Swart, Hermann Rocher, Sulina Green, and Johannes Erasmus. Stellenbosch: sun Press, 2010.

Swenson, Donald. Society, Spirituality, and the Sacred: A Social Scientific Introduction. Peterborough, Ont.; New York,ny: Broadview Press, 1999.

Ter Haar, Gerrie. "Religion and Development: Introducing a New Debate.” Pages 3-25 in Religion and Development: Ways of Transforming the World. Edited by Gerrie ter Haar. New York, ny: Columbia University Press, 2011.

The World Bank, "Michael Woolcock: Lead Social Development Specialist, Development Research Group." No date. Online: http://www.worldbank.org/en/about/ people/m/michaelwoolcock

Unruh, Heidi Rolland, and Ronald J. Sider. Saving Souls, Serving Society: Understanding the Faith Factor in Church-Based Social Ministry. Oxford: Oxford University Press, 2005.

Wepener, Cas, and Johan Cilliers. "Ritual and the Generation of Social Capital in Contexts of Poverty." Pages 417-430 in Religion and Social Development in Post-Apartheid South Africa: Perspectives for Critical Engagement. Edited by Ignatius Swart, Hermann Rocher, Sulina Green, and Johannes Erasmus. Stellenbosch: sun Press, 2010.

Wepener, Cas, Ignatius Swart, Gerrie ter Haar, and Marcel Barnard. “The Role of Religious Ritual in Social Capital Formation for Poverty Alleviation and Social Development: Theoretical and Methodological Points of Departure of a South African Exploration." $r \& t 22$, no. $3 \& 4$ (2010): 61-82.

Wepener, Cas, Ignatius Swart, Gerrie ter Haar, and Marcel Barnard. Bread\& Wine \& Kentucky Fried Chicken: A Ritual Lens on Social Capital Formation in African Independent Churches in South Africa. Unpublished manuscript submitted to Peeters Publishers, February 2017.

Woolcock, Michael. "Social Capital and Economic Development:Towards a Theoretical Synthesis and Policy Framework." Theory and Society 27, no. 2 (1998): 151-208.

Woolcock, Michael, and Deepa Narayan. "Social Capital: Implications for Development Theory, Research, and Policy”, The World Bank Research Observer 15, no. 2 (2000): 225-249.

Woolcock, Michael. "The Place of Social Capital in Understanding Social and Economic Outcomes." Development Research Group, The World Bank, and Kennedy School of Government, Harvard University. Online: www.oecd.org/innovation/research/1824913.pdf, 2001. 